Portofolio Sebagai Model, Oleh: Salma Sunaiyah

\title{
PORTOFOLIO SEBAGAI MODEL PEMBELAJARAN AKTIF
}

\author{
Salma Sunaiyah*
}

\begin{abstract}
Abstrak
Salah satu tantangan mendasar dalam pembelajaran dewasa ini adalah mencari strategi proses pembelajaran inovatif. Hal ini dirasakan mendesak seiring dengan perkembangan dan kemajuan ilmu pengetahuan dan teknologi yang semakin pesat. Dengan teknologi siswa dapat belajar dari luar kelas seperti dari lingkungan masyarakat, melalui media cetak maupun elektronik serta sarana-sarana lain yang tersedia.

Dengan belajar seperti itu siswa akan lebih leluasa menuangkan gagasan atau ide-idenya yang dibangun berdasarkan informasi dari berbagai sumber. Model pembelajaran portofolio merupakan jawaban dari pembelajaran inovatif. Portofolio sebagai model pembelajaran dapat digolongkan ke dalam metode resitasi atau metode pemberian tugas. Pemberian tugas portofolio lebih mementingkan proses dan bukan sekedar hasil belajar.
\end{abstract}

Kata Kunci : model pembelajaran, Portofolio

\section{Pendahuluan}

Pemberlakuan kurikulum berbasis kompetensi secara otomatis berpengaruh terhadap komponen pengajaran lainya. Materi berubah sesuai dengan tuntutan kurikulum, metode berubah sesuai dengan tujuan dan jenis materi. Maka setiap kali ganti kurikulum senantiasa diiringi dengan tawaran pendekatan yang digunakan. Konsep-konsep pembelajaran yang ditawarkan banyak bermunculan, seperti tawaran konsep pembelajaran berbasis portofolio (portofolio based learning) yang merupakan satu bentuk perubahan pola pikir di atas, yaitu suatu inovasi pembelajaran yang dirancang untuk membantu peserta didik memahami teori secara mendalam melalui pengalaman belajar praktikempirik.

\footnotetext{
* Dosen jurusan Tarbiyah STAIN Kediri.
} 
Model pembelajaran ini dapat: (1) menjadi program pendidikan yang mendorong kompetensi, tanggung jawab, dan partisipasi peserta didik, belajar menilai dan mempengaruhi kebijakan umum (public policy), memberanikan diri untuk berperan serta dalam kegiatan antar peserta didik, antar sekolah, dan antar anggota masyarakat; (2) model pembelajaran portofolio juga merupakan model pembelajaran aktif yang mengakomodasi perbedaan potensi dan sekaligus memberikan seluasluasnya untuk menumbuhkan kreativitas peserta didik, agar kecerdasanya berkembang secara optimal dan proporsional. Model pembelajaran aktif menitikberatkan pada pengembangan afeksi dan perilaku yang didasarkan pada kebutuhan belajar (learning need based) peserta didik, berdasarkan pengalaman belajar (experiental learning). Karena itu pembelajaran aktif berpusat pada peserta didik (participant centered); dan (3) portofolio bukan hanya menunjukkan bagaimana murid berpikir dan proses apa yang digunakan untuk mencapai hasil tertentu, tetapi juga bagaimana mereka dan hasil kerja mereka berubah selama satu tahun ajaran. ${ }^{1}$ Begitu pentingnya pembelajaran portofolio, maka dalam tulisan ini mencoba untuk menjelaskan bagaimana sebenarnya konsep pembelalajaran portofolio dilaksanakan.

\section{Hakikat Portofolio}

Portofolio berasal dari bahasa Inggris "portofolio" yang berarti dokumen atau surat-surat. Portofolio dapat juga diartikan sebagai kumpulan kertas-kertas berharga dari suatu pekerjaan tertentu. Pengertian portofolio di sini adalah suatu kumpulan pekerjaan siswa dengan maksud tertentu dan terpadu yang diseleksi menurut panduanpanduan yang ditentukan. Panduan-panduan ini beragam tergantung pada mata pelajaran dan tujuan penilaian portofolio. ${ }^{2}$ Paulson Meyer dalam Rofiuddin memberikan definisi portofolio sebagai "suatu kumpulan pekerjaan siswa yang menunjukkan upaya siswa, kemajuan dan pencapaian dalam satu bidang atau lebih. Kumpulan harus termasuk partisipasi siswa dalam memilih isi, standar atas pilihan, standar dalam memutuskan manfaat dan keterangan dari pemikiran pribadi siswa."3

${ }^{1}$ Daniel Muijs dan David Reynold, Efective Teaching Teori dan aplikasi (Yogyakarta: Pustaka Pelajar, 2008), h. 374.

2 Arnien Fajar, Portofolio dalam Pembelajaran IPS (Bandung: PT Remaja Rosda Karya, 2005), h. 47.

3 Rofiuddin, Guidelines for Portofolio Assessment in Teaching English (Malang: Indonesian Departement Post Graduate State University of Malang, 2001), h. 2 . 
Portofolio Sebagai Model, Oleh: Salma Sunaiyah

Yuliani mengemukakan beberapa definisi portofolio menurut beberapa tokoh pendidikan. ${ }^{4} \mathrm{Di}$ antaranya, portofolio adalah koleksi pekerjaan peserta didik yang menunjukkan segala usaha peserta didik, kemajuan dan pencapaian belajar dalam satu bidang tertentu atau lebih. Portofolio harus menunjukkan koleksi pekerjaan terbaik peserta didik atau usaha terbaiknya, contoh terbaik dari pengalaman kerjanya yang berhubungan dengan hasil belajar yang akan diukur, dan dokumendokumen yang sesuai dengan pertumbuhan dan perkembangan ke arah penguasaan hasil belajar yang diidentifikasi (Paulson \& Meyer, dalam Winter, 1989). Menurut pendapat lain, portofolio adalah deskripsi tentang pengalaman yang menghasilkan pengetahuan, keterampilan dan kemampuan dari seseorang secara tertulis yang diajukan kepada Lembaga Pendidikan Tenaga Kependidikan (LPTK) untuk mendapatkan penghargaan/pengakuan kredit untuk mata kuliah dalam program tersebut (Djajadisastra, 1992).

Ada juga yang memahami portofolio sebagai sejenis klipping atau album foto yang menyimpan kemajuan dan kegiatan suatu program dan pesertanya, dan mempertunjukkannya kepada pihak-pihak yang berkepentingan di dalam maupun di luar program (Cole, Ryan dan Kick, dalam Koretz, 1992). Di samping itu, ada juga yang berpendapat bahwa portofolio merupakan berkas pengkajian terhadap suatu permasalahan atau topik tertentu yang harus dikaji secara mendalam dan menyeluruh, yang dimulai dari proses pengumpulan, penggabungan dan interpretasi informasi untuk mengambil keputusan. Rancangan portofolio yang baik haruslah berisikan gambaran kerja yang dapat menghasilkan pengetahuan, keterampilan dan kemampuan yang dibuat secara tertulis dan dapat diselesaikan peserta didik sesuai dengan tujuan yang diharapkan, khususnya yang menghendaki cara berpikir yang kompleks dengan penggunaan kumpulan berbagai macam sumber rujukan dalam bentuk klipping (Yuliani Nurani, 1996). Sementara itu, portofolio yang dimaksud dalam program Pengakuan Pengalaman Kerja dan Hasil Belajar (PPKHB) adalah bukti fisik atau dokumen yang menggambarkan pengalaman kerja dan hasil belajar pada satuan pendidikan serta berbagai pelatihan yang pernah diikuti oleh seorang guru (Departemen Pendidikan Nasional, 2009).

Dalam tulisan ini, penulis memahami portofolio sebagai suatu koleksi pekerjaan peserta didik yang menunjukkan segala usaha peserta

\footnotetext{
${ }^{4}$ Yuliani Nurani Sujiono, Mengajar dengan Portofolio (Jakarta: PT Indeks,
} 2009), h. 7.

Vol. 22 Nomor. 1 Januari 2011 
didik, kemajuan dan pencapaian belajar dalam satu bidang tertentu atau lebih.

\section{Karakteristik Portofolio yang Efektif ${ }^{5}$}

Walaupun terdapat berbagai jenis pendekatan dalam pengembangan portofolio namun ada beberapa karakteristik utama yang dapat menggambarkan keefektifan dari pemanfaatan portofolio:

1. Secara jelas mencerminkan hasil belajar peserta didik yang diidentifikasikan dalam kurikulum inti, dimana peserta didik diharapkan mempelajarinya.

2. Memusatkan perhatian pada pengalaman belajar peserta didik yang didasarkan pada performance (performance-based learning experience), sama halnya dengan perolehan pengetahuan, keterampilan dan sikap-sikap kunci.

3. Berisi tentang contoh-contoh pekerjaan yang meliputi seluruh pekerjaan dalam kurun waktu tertentu.

4. Berisi pekerjaan tertentu yang mewakili berbagai alat pengukuran yang berbeda-beda.

5. Berisi berbagai contoh pekerjaan dan evaluasi dari pekerjaan tersebut oleh peserta didik, teman, guru, bahkan dimungkinkan adanya reaksi dari orangtua.

Sedangkan dalam bukunya Rofiudin dijelaskan bahwa

Karakteristik kunci dari penilaian portofolio:

1. Portofolio adalah suatu bentuk penilaian bahwa siswa bekerjasama dengan gurunya.

2. Portofolio bukan hanya kumpulan pekerjaan siswa tetapi juga pilihan - siswa harus dilibatkan dalam memilih dan memutuskan bagian yang dimasukkan.

3. Portofolio memberikan contoh dari pekerjaan siswa yang menunjukkan pertumbuhan lebih. Dengan bercermin pada hasil belajar mereka (penilaian pribadi), siswa memulai untuk mengidentifikasi kekuatan dan kelemahan dalam pekerjaan mereka. Kelemahan-kelemahan ini kemudian menjadi tujuan perbaikan

4. Standar dalam pemilihan dan penilaian isi kumpulan harus dijelaskan kepada guru dan siswa pada permulaan proses. ${ }^{6}$

\footnotetext{
${ }^{5}$ Ibid., h. 10.

6 Rofiudin, Guidelines for Portofolio Assessment in Teaching English
} (Malang: Indonesian Departement Post Graduate State University of Malang, 2001), h. 2. 
Portofolio Sebagai Model, Oleh: Salma Sunaiyah

\section{Model Pembelajaran Portofolio}

Secara etimologis, ${ }^{7}$ istilah model berasal dari bahasa latin yaitu modulus atau modul yang mempunyai pengertian kecil; sesuai dengan istilah yang digunakan dalam penelitian pengembangan, model merujuk kepada 2 hal, yaitu: (1) contoh atau sesuatu yang ditiru dan (2) bentuk, pola atau rancangan. Lebih jelas lagi model biasanya digunakan untuk hal-hal yang bersifat: (1) menggambarkan sesuatu, (2) menjelaskan suatu proses, (3) mengkaji atau menganalisis sesuatu system, (4) menggambarkan dari suatu situasi, dan (5) bersifat memprediksi sesuatu keputusan yang akan diambil.

Portofolio sebagai model pembelajaran dapat digolongkan ke dalam metode resitasi atau metode pemberian tugas. Pemberian tugas portofolio lebih mementingkan proses dan bukan sekedar hasil belajar, sesuai dengan pendekatan cara mengaktifkan siswa dalam belajar ( $\mathrm{SAL}=$ Student Active Learning). Dalam pelaksanaannya dengan sistem SKS dapat dibagi menjadi dua, yaitu: (1) secara penuh dan (2) secara tidak penuh. ${ }^{8}$

Secara penuh, kegiatan belajar terstruktur dan mandiri $(80 \%)$ lebih mendominasi kegiatan belajar tatap muka (20\%). Peran pengajar hanya di awal dan di akhir kegiatan belajar sepanjang semester. Pencapaian tujuan pembelajaran khusus (TPK) seluruhnya dilakukan melalui kegiatan terstruktur dan mandiri dan kemudian dilanjutkan dengan pertanggungjawaban tugas, yang dikenal dengan istilah kolokium dalam bentuk diskusi ilmiah, seminar, simposium atau bentuk lain yang telah diatur oleh lembaga pendidikan yang bersangkutan.

Secara tidak penuh kegiatan belajar tatap muka, terstruktur dan mandiri dilakukan secara berimbang (50\%:50\%). Peran pengajar masih lebih mendominasi dalam bentuk kegiatan tatap muka. Biasanya hanya dipilih beberapa Tujuan Pembelajaran Khusus (TPK)/ indikator saja dari sekian jumlah TPK yang ada untuk dijadikan tugas portofolio. Pertanggungjawaban tugas dilakukan di akhir kegiatan belajar dalam bentuk diskusi kelompok dan dilanjutkan dengan diskusi paripurna.

Teknik penugasan terdapat 4 (empat) fase, yaitu: (1) fase pemberian tugas, aktivitasnya adalah pengajar memberikan tugas kepada peserta didiknya termasuk berbagai informasi tentang prosedur kerja yang akan dilaksanakan; (2) fase pelaksanaan tugas, dengan aktivitasnya adalah peserta didik melaksanakan tugas yang harus

\footnotetext{
${ }^{7}$ Ibid., h. 26.

${ }^{8}$ Ibid., h. 11-12.
}

Vol. 22 Nomor. 1 Januari 2011 
dikerjakan dan diselesaikannya; (3) fase reses (tugas terstruktur dan belajar mandiri) dengan aktivitasnya adalah melaksanakan tugas di luar jadwal perkuliahan tatap muka, tetapi kegiatan tugas belajar tersebut memang sengaja dirancang dan dikembangkan oleh pengajar dan juga dilakukan monitoring kegiatan belajar terhadap kemajuan pelaksanaan tugas peserta didik secara bertahap; (4) fase pertanggungjawaban tugas, dengan aktivitasnya adalah peserta didik mempertanggungjawabkan tugas yang telah dilaksanakannya kepada pengajar dan teman lainnya.

Portofolio yang baik membutuhkan rancangan yang dapat menjawab pertanyaan-pertanyaan berikut secara berkesinambungan:

1. Apakah tujuan penugasan portofolio itu,

2. Tugas apa yang harus masuk dalam pengumpulan portofolio,

3. Apa standar dan kriteria yang akan digunakan,

4. Bagaimana dijaminnya kemantapan penetapan skoring dan penjurian,

5. Apakah hasilnya valid untuk tujuan yang telah ditentukan, dan

6. Bagaimana hasil-hasil itu digunakan.

Teknik Penugasan Portofolio ${ }^{9}$

\begin{tabular}{|c|c|c|}
\hline Fase & $\begin{array}{l}\text { Kegiatan } \\
\text { Pengajar }\end{array}$ & $\begin{array}{c}\text { Kegiatan Peserta } \\
\text { Didik }\end{array}$ \\
\hline $\begin{array}{l}\text { I. Pemberian } \\
\text { tugas }\end{array}$ & $\begin{array}{l}\text { - Pengenalan } \\
\text { - Informasi tugas }\end{array}$ & $\begin{array}{l}\text { - Pembagian kelompok } \\
\text { - Pemilihan topik }\end{array}$ \\
\hline $\begin{array}{l}\text { II. Pelaksanaan } \\
\text { tugas }\end{array}$ & $\begin{array}{l}\text { - Sebagai nara sumber } \\
\text { - Monitoring minimal } \\
1 \text { kali seminggu }\end{array}$ & $\begin{array}{l}\text { - Menyusun berkas } \\
\text { portofolio }\end{array}$ \\
\hline $\begin{array}{l}\text { III. Reses } \\
\text { (terstruktur \& } \\
\text { mandiri) }\end{array}$ & $\begin{array}{l}\text { - Monitoring kegiatan } \\
\text { belajar } \\
\text { - Nara sumber }\end{array}$ & $\begin{array}{l}\text { - Aktivitas individu: } \\
\text { - Mencari \& menemukan } \\
\text { sumber bacaan } \\
\text { - Aktivitas kelompok: } \\
\text { - Menyusun portofolio } \\
\text { - Menyusun kliping } \\
\text { - Diskusi kelompok kecil } \\
\text { - Menyiapkan penyajian } \\
\text { berkas portofolio } \\
\end{array}$ \\
\hline $\begin{array}{l}\text { IV.Pertanggungja } \\
\text { waban tugas }\end{array}$ & $\begin{array}{l}\text { - Sebagai moderator } \\
\text { - Sebagai evaluasi }\end{array}$ & $\begin{array}{l}\text { - Diskusi penyajian berkas } \\
\text { portofolio di kelas } \\
\text { - Memperbaiki, } \\
\text { menyempurnakan dan } \\
\text { mengumpulkan berkas } \\
\text { portofolio }\end{array}$ \\
\hline
\end{tabular}

${ }^{9}$ Yuliani, Mengajar dengan Portofolio, h. 36 
Portofolio Sebagai Model, Oleh: Salma Sunaiyah

Karena dalam tulisan ini model pembelajaran aktif yang fokusnya pada siswa, maka yang dijelaskan hanya kegiatan siswa pada masing-masing fase. Kegiatan pada masing-masing fase sebagai berikut:

a. Fase pemberian tugas

Pada fase ini diharapkan peserta didik akan dapat memahami maksud dan tujuan, manfaat serta teknik pelaksanaan tugas portofolio secara terperinci. Adapun langkah-langkah yang perlu diperhatikan sebagai berikut:

1. Mendengarkan penjelasan dari pengajar tentang hakikat portofolio dan teknik pelaksanaannya.

2. Mempelajari panduan penyusunan teknik penugasan portofolio.

3. Memilih dan menentukan teman dalam kelompok.

4. Memilih dan menetapkan topik yang akan dikaji.

5. Menentukan jadwal kegiatan belajar dalam kelompok kecil.

- Waktu pertemuan diskusi

- Tugas individu dalam kelompok

b. Fase pelaksanaan tugas

Pada fase ini peserta didik diharapkan akan dapat melaksanakan tugas portofolio sesuai dengan langkah-langkah yang telah dipelajari dan bekerja sesuai jadwal yang telah ditentukan. Adapun hal-hal yang perlu diperhatikan sebagai berikut:

1. Mencari dan menemukan sendiri berbagai sumber belajar yang akan dijadikan referensi dalam menunjang pengkajian topik (tugas individu dalam kelompok).

2. Menyusun draft portofolio sesuai topik yang telah dipilih.

3. Menyusun berkas portofolio berupa pengkajian topik secara mendalam dan menyeluruh dalam diskusi kelompok kecil.

c. Fase reses (tugas terstruktur dan mandiri)

Pada fase ini peserta didik diharapkan akan dapat menyusun berkas portofolio lengkap dengan lampiran berupa kliping sumber rujukan dalam rentang waktu tertentu secara terstruktur dan mandiri di luar jam perkuliahan tatap muka. Adapun hal-hal yang perlu diperhatikan sebagai berikut:

1. Mengadakan konsultasi langsung dengan pengajar sesuai jadwal yang telah ditentukan (batas minimal ditentukan) sampai saat penyajian diskusi

2. Mengkonsultasikan berbagai sumber rujukan yang relevan dengan topik yang dibahas

3. Mengkonsultasikan isi batang tubuh portofolio

Vol. 22 Nomor. 1 Januari 2011 
Portofolio Sebagai Model, Oleh: Salma Sunaiyah

4. Menyusun lampiran berupa fotokopi sumber rujukan yang sesuai dan berhubungan dengan topik yang dikaji.

d. Fase pertanggungjawaban tugas

Pada fase ini peserta didik diharapkan akan dapat mempertanggungjawabkan tugas penyusunan berkas pengkajian portofolio dalam presentasi diskusi di kelas dihadapan pengajar dan anggota kelompok lain. Adapun hal-hal yang perlu diperhatikan sebagai berikut:

1. Mendengarkan penjelasan dari pengajar sebagai moderator tentang peraturan diskusi kelas.

2. Membagikan berkas portofolio lengkap kepada pengajar dan kelompok lain.

3. Menyajikan hasil diskusi kelompok kecil berupa berkas pengkajian portofolio lengkap.

4. Mengumpulkan saran, ide tanggapan dan kritik baik dari pengajar dan anggota kelompok lainnya baik balikan secara lisan maupun tulisan sebagai bahan perbaikan.

5. Memperbaiki dan menyempurnakan berkas portofolio lengkap sebagai hasil penyempurnaan, berupa:

- Batang tubuh (makalah)

- Lampiran (kliping = fotocopy sumber rujukan)

e. Kegiatan Belajar

Terdapat lima kegiatan utama yang akan dilaksanakan oleh peserta didik dalam rangka penugasan portofolio, sebagai berikut:

1. Melaksanakan tugas kelompok

Tugas portofolio dibuat secara berkelompok dan merupakan prasyarat untuk mendapatkan nilai individu. Anggota kelompok dipilih dan ditentukan sendiri oleh masing-masing peserta didik. Setiap kelompok akan mengkaji satu topik pilihan yang akan ditentukan secara bersama-sama.

2. Mencari dan mengkaji sumber rujukan

Mencari dan menemukan sendiri sumber belajar terutama berupa sumber rujukan yang akan menunjang pengkajian topik merupakan tugas individu di dalam kelompok. Topik hendaknya dikaji secara mendalam dan menyeluruh dengan minimal menggunakan 8 sumber rujukan dengan 2 sumber berbahasa asing (Inggris)

3. Menyusun isi dan sistem penulisan batang tubuh

Penyusunan portofolio yang merupakan berkas pengkajian terdiri dari: 
Portofolio Sebagai Model, Oleh: Salma Sunaiyah

Batang tubuh: berisikan pembahasan topik kelompok dengan struktur isi yang disarankan sebagai berikut;

PENDAHULUAN, berisikan latar belakang topik yang dibahas;

PEMBAHASAN, berisikan pengertian, istilah dan konsep yang terkandung dan atau yang berkaitan dengan topik;

KESIMPULAN, berisikan inti dari pokok-pokok yang dibahas dan saran-saran terutama yang berkaitan dengan pemanfaatannya dalam proses pendidikan dan pembelajaran;

Catatan: Isi batang tubuh (pendahuluan, pembahasan dan kesimpulan tidak lebih dari 25 halaman kuarto dan diketik 2 spasi).

DAFTAR PUSTAKA, ditulis lengkap dari seluruh sumber rujukan yang digunakan.

Lampiran/Dokumentasi: berisikan fotocopy sumber bacaan yang dijadikan referensi dan/atau menunjang pengkajian topik dilampirkan di bagian akhir dari portofolio.

4. Menyajikan isi berkas portofolio

5. Mengumpulkan tugas akhir

Sedangkan teori belajar yang mendasari model pembelajaran portofolio menurut Yuliani "(1) model belajar penemuan Jeremi Bruner, (2) model belajar bermakna David Ausubel, dan (3) model pembelajaran Gagne." 10

\section{Model Belajar Penemuan Bruner}

Menurut Bruner inti belajar adalah cara-cara bagaimana orang memilih, mempertahankan dan mentransformasikan informasi secara aktif. Pendekatannya terhadap belajar ada dua asumsi yaitu: (1) perolehan pengetahuan merupakan suatu proses interaktif, artinya orang yang belajar berinteraksi dengan lingkungan secara aktif dan (2) orang mengkonstruksikan pengetahuannya dengan menghubungkan informasi yang masuk dengan informasi yang disimpan yang diperoleh sebelumnya. ${ }^{11}$ Jerome Bruner ${ }^{12}$ menganggap manusia sebagai pemroses, pemikir, dan pencipta informasi. Cara-cara bagaimana orang memilih,

\footnotetext{
${ }^{10}$ Ibid., h. 27.

${ }^{11}$ Ratna Willis Dahar, Teori-teori Belajar (Bandung: Departemen Pendidikan dan kebudayaan, 1988), h. 119

12 Ratna Willis Dahar. Teori-teori Belajar (Jakarta: Departemen Pendidikan dan Kebudayaan Direktorat Jenderal Pendidikan Tinggi Proyek Pengembangan Lembaga Pendidikan Tenaga Kependidikan, 1988), h. 118.
}

Vol. 22 Nomor. 1 Januari 2011 
mempertahankan, dan mentransformasi informasi secara aktif, dan inilah menurut Bruner inti dari belajar.

Selanjutnya Bruner yang dikutip oleh Dahar (1988) mengemukakan bahwa belajar melibatkan tiga proses yang berlangsung hampir bersamaan: (1) memperoleh informasi baru; (2) transformasi informasi; dan (3) menguji relevansi dan ketepatan pengetahuan. ${ }^{13}$

Lebih dalam Bruner menganggap bahwa belajar penemuan (discovery learning) sesuai dengan pencarian pengetahuan secara aktif oleh peserta didik dan dengan sendirinya memberikan hasil yang paling baik. Berusaha sendiri untuk mencari pemecahan masalah serta pengetahuan yang menyertainya akan menghasilkan pengetahuan yang benar-benar bermakna. Belajar yang diperoleh dengan belajar penemuan menunjukkan beberapa kebaikan. Pertama, pengetahuan itu bertahan lama atau lama dapat diingat atau lebih mudah diingat, bila dibandingkan dengan pengetahuan yang dipelajari dengan cara-cara lain. Kedua, hasil belajar penemuan mempunyai efek transfer yang lebih baik daripada hasil lainnya. Ketiga, secara menyeluruh belajar penemuan meningkatkan penalaran peserta didik dan kemampuan untuk berpikir secara bebas. Secara khusus belajar penemuan melatih keterampilan-keterampilan kognitif peserta didik untuk menemukan dan memecahkan masalah tanpa pertolongan orang lain. ${ }^{14}$

Belajar penemuan dapat membangkitkan keingintahuan peserta didik, memberi motivasi untuk bekerja terus sampai menemukan jawaban-jawaban yang dicari dan menimbulkan rasa puas pada diri peserta didik. Selain itu pendekatan ini dapat mengajarkan keterampilan-keterampilan memecahkan masalah tanpa pertolongan orang lain, dan meminta peserta didik untuk menganalisa dan memanipulasi informasi, tidak hanya menerima saja.

\section{Model Belajar Bermakna Ausubel}

Ausubel menyatakan bahwa belajar bermakna hanya terjadi bila peserta didik mencari dan menemukan sendiri pengetahuannya. Bagi Ausubel belajar bermakna merupakan suatu proses mengkaitkan informasi baru pada konsep-konsep relevan yang terdapat dalam struktur kognitif seseorang.

Ia juga mengemukakan tentang prasyarat-prasyarat dari belajar bermakna sebagai berikut: materi yang dipelajari harus bermakna secara

\footnotetext{
${ }^{13}$ Ratna willis Dahar, h. 122.

${ }^{14}$ Ibid., h. 126.
} 
potensial yang tergantung pada dua faktor, yaitu: (1) suatu materi harus memiliki kebermaknaan logis; (2) gagasan-gagasan yang relevan harus terdapat dalam struktur kognitif seseorang dengan memperhatikan pengalaman, tingkat perkembangan, intelegensia dan usia seseorang. ${ }^{15}$

Inti teori belajarnya adalah agar terjadi belajar bermakna, konsep atau informasi baru harus dikitkan dengan konsep-konsep yang telah ada dalam struktur kognitif peserta didik. Untuk menerapkan teori Ausubel dalam proses pembelajaran, ada satu konsep ataupun prinsip yang menarik yaitu pengatur awal (advance organizer) pada awal pelajaran yang dilakukan untuk: (1) mengarahkan peserta didik ke materi yang akan dipelajari, (2) menolong peserta didik untuk mengingat kembali informasi yang berhubungan yang dapat digunakan untuk menanamkan pengetahuan baru, (3) menyiapkan mental agar peserta didik siap menerima informasi baru, biasanya ini disajikan sebelum materi baru tersebut. ${ }^{16}$

\section{Model Belajar Gagne}

Gagne dalam Dahar (1988) mengemukakan dalam suatu tindakan belajar terdapat delapan fase belajar. Fase-fase itu merupakan kejadian-kejadian eksternal yang dapat distrukturkan oleh orang yang peserta didik atau pengajar. Setiap fase dipasangkan dengan suatu proses yang terjadi dalam pikiran peserta didik yang belajar. Di bawah ini akan diuraikan hubungan antara fase-fase dan kejadian belajar. Setiap fase diberi nama, dan di bawah masing-masing fase terlihat satu kotak yang menunjukkan proses internal utama, yaitu kejadian-kejadian belajar yang berlangsung selama fase itu.

Berikut akan dijelaskan fase belajar dan kejadian belajar yang menyertainya:

a. Fase Motivasi

Kejadian belajar: (a) mengaktifkan motivasi atau kegiatan memotivasi peserta didik untuk belajar, misalnya dengan mengemukakan kegunaan pelajaran tersebut; (b) memberitahu tujuan-tujuan belajar yang berguna untuk membantu memusatkan perhatian peserta didik terhadap aspek-aspek yang relevan tentang pelajaran.

b. Fase Pengenalan

${ }^{15}$ Yuliani Nurani Sujiono, Mengajar dengan Portofolio (Jakarta: PT Indeks, 2010), h. 28.

${ }^{16}$ Ratna Willis Dahar, Teori-teori Belajar, h. 144-149.

Vol. 22 Nomor. 1 Januari 2011 
Portofolio Sebagai Model, Oleh: Salma Sunaiyah

Kejadian belajar: mengarahkan perhatian, terdapat dua bentuk perhatian yang berfungsi: (a) membuat peserta didik siap menerima stimulus-stimulus; (b) persepsi selektif yaitu dengan cara memberikan penekanan pada ucapan atau menggaris bawahi suatu kata atau kalimat yang harus menjadi pusat perhatian peserta didik.

c. Fase Perolehan

Kejadian belajar: (a) merangsang ingatan tentang pelajaran yang telah lampau; (b) menyediakan bimbingan belajar dengan jalan mengkaitkan informasi baru dengan pengalaman pesrta didik

d. Fase Retensi dan Fase Pemanggilan

Kejadian belajar: penyimpanan memori dan pemanggilan kembali memori tersebut. Agar isi pelajaran dapat bertahan lama (retensi) dalam memori peserta didik dapat dilakukan dengan cara sering mengulangi pelajaran, memperbanyak contoh dan latihan soal dan menyajikan kembali pengetahuannya pada presentasi diskusi.

e. Fase Generalisasi

Kejadian belajar: melancarkan transfer belajar yaitu dengan cara menerapkan apa yang telah dipelajari pada situasi baru melalui tugas pemecahan masalah ataupun dalam diskusi kelompok

f. Fase Penampilan

Kejadian belajar: memperlihatkan penampilan atau hasil belajar untuk mengetahui seberapa besar tujuan belajar telah tercapai. Kegiatan ini dapat dilakukan sesegera mungkin sepanjang proses pembelajaran.

g. Fase Umpan Balik

Kejadian belajar: pemberian reinforcement/ penguatan yang didapat dari umpan balik yang dapat dilakukan dengan pemberian tes ataupun dengan mengamati perilaku peserta didik.

Berdasarkan uraian dari ketiga tokoh teori belajar kognitif di atas dapat disimpulkan bahwa dalam belajar penemuan, pengajar tidak begitu mengendalikan proses pembelajaran peserta didik di kelas. Pengajar hendaknya lebih mengarahkan pelajaran pada penemuan dan pemecahan masalah. Sedangkan penilaian hasil belajar penemuan meliputi pemahaman tentang prinsip-prinsip dasar suatu bidang studi dan aplikasi prinsip-prinsip itu pada situasi baru. 


\section{Kesimpulan}

Secara etimologi portofolio berasal dari bahasa Inggris "portofolio" yang artinya dokumen atau surat-surat. Sedangkan secara terminology portofolio diartikan sebagai suatu koleksi pekerjaan peserta didik yang menunjukkan segala usaha peserta didik, kemajuan dan pencapaian belajar dalam satu bidang tertentu atau lebih. Portofolio harus menunjukkan koleksi pekerjaan terbaik peserta didik atau usaha terbaiknya, contoh terbaik dari pengalaman kerjanya yang berhubungan dengan hasil belajar yang akan diukur dan dokumen-dokumen yang sesuai dengan pertumbuhan dan perkembangan ke arah penguasaan hasil belajar yang diidentifikasi.

Portofolio sebagai model pembelajaran dapat digolongkan ke dalam metode resitasi atau metode pemberian tugas. Pemberian tugas portofolio lebih mementingkan proses dan bukan sekedar hasil belajar, sesuai dengan pendekatan cara mengaktifkan siswa dalam belajar ( $\mathrm{SAL}=$ Student Active Learning). Penugasan portofolio didukung oleh teori belajar cognitivenya Bruner, Ausubel, dan Gagne, bahwa yang penting dalam belajar adalah proses dan bukan hanya sekedar hasil. Manakala proses belajar berlangsung secara maksimal, maka besar kemungkinan hasilnya akan optimal pula. 


\section{Daftar Pustaka}

Cahyani, Isah, Pembelajaran Bahasa Indonesia, Jakarta: Dirjen Pendis Depag RI, 2009.

Dahar, Ratna Wilis, Teori-teori Belajar, Jakarta: Departemen Pendidikan dan Kebudayaan Direktorat Jenderal Pendidikan Tinggi Proyek Pengembangan Lembaga Pendidikan Tenaga Kependidikan, 1988.

Effendy, Ahmad Fuad, Metodologi Pengajaran Bahasa Arab, Malang: Misykat, 2009.

Fajar, Arnien, Portofolio dalam Pembelajaran IPS, Bandung: PT Remaja Rosda Karya, 2005.

Hariyani, Nanik Dwi, "Pembelajaran Bahasa Arab Berbasis Portofolio", Al-Arabiyah, , Vol 2 (2006), h. 29-48.

Kemp, Judy dan Debby Toperoff, Guidelines for Portofolio assessment in Teaching English, Malang: Indonesian Departement Post Graduate State Universityof Malang, 2001.

Muijs, Daniel dan David Reynolds, Effective Teaching teori dan aplikasi, Yogyakarta: Pustaka Pelajar,2008

Sujiono, Yuliani Nurani, Mengajar dengan Portofolio, Jakarta: PT Indeks, 2009. 